\title{
Professional Care in Home for Children and Teenagers with Special Health Needs: An Integrative Review
}

Paloma Mayara Vieira de Macena Lima

https://orcid.org/0000-0002-0856-9993 Universidade Federal da Paraíba, Brazil. paloma.mayara@academico.ufpb.br

Leiliane Teixeira Bento Fernandes

https://orcid.org/0000-0003-2643-5638 Universidade Federal da Paraíba, Brazil. leiliane.fernandes@academico.ufpb.br

Mariana Matias Santos

https://orcid.org/00oo-0002-4539-4707 Universidade Federal da Paraíba, Brazil. mariana.santos@unipe.edu.br

Neusa Collet

https://orcid.org/0000-0002-4795-0279 Universidade Federal da Paraíba, Brazil. neucollet@ccs.ufpb.br

Beatriz Rosana Gonçalves de Oliveira Toso

https://orcid.org/0000-0001-7366-077X Universidade Estadual do Oeste do Paraná, Brazil. beatriz.oliveira@unioeste.br

Elenice Maria Cecchetti Vaz

https://orcid.org/0000-0001-6149-1892 Universidade Federal da Paraíba, Brazil. emcv@academico.ufpb.br

DOI: 10.5294/aqui.2022.22.1.5

Received: 14/04/2021 Submitted to pairs: 29/07/2021 Accepted in pairs: 12/11/2021

Approved: 16/11/2021
Para citar este artículo / To reference this article / Para citar este artigo Lima PMVM, Fernandes LTB, Santos MM, Collet N, Toso, Beatriz RGO, Vaz EMC. Professional Care in Home for Children and Teenagers with Special Health Needs: An Integrative Review. Aquichan. 2022;22(1):e2215. DOI: https://doi.org/10.5294/ aqui.2022.22.1.5 
Thematic: evidence-based practice.

Contribution to the discipline: the results of the present study show that, worldwide, home services with relationships with necessities and special conditions improve their quality of life and that of their caregivers or family members by promoting support to health technologies and relief of symptoms resulting from health disorders, in addition to reducing caregiver or family burden. These actions are innovated, therefore, with technological advances, it is possible to perform a remote monitoring or use digital technologies that enable the approximation of the professional with the caregiver, as well as the recovery of the health of these children. This favors nursing and professionals who work at home in the performance of humanized and comprehensive care. 


\section{Abstract}

Objective: Analyzing the results of scientific publications on professional home care for children and teenagers with special health needs. Materials and method: An integrative review with articles published between 2009 and 2020 conducted in the BDEnf, Lilacs, Medline/ PubMed databases and in the SciELO electronic library. The data were analyzed in four stages: data reduction; display of the data; comparison of data; drawing and verification of completion. Results: There were identified 5,641 articles; after the application of the inclusion and exclusion criteria and disposal of duplicates, 637 articles were chosen for the reading of titles and abstracts, of which 61 were selected for full reading and of these, 28 composed the final sample. The offer of remote support actions and concern in training caregivers regarding the technical-scientific aspects of home care was identified, in addition to promoting the improvement of the quality of life of children/teenagers and their families. A gap was evidenced regarding the identification and management of pain by home service professionals. Conclusions: The performance of home services to this specific population focus-

es on the demands of care with health technologies and on promoting symptom relief, reducing the workload of caregivers and assisting in dehospitalization.

\section{Keywords (Source: DeCS)}

Homebound persons; home nursing; caregiver; child; teenager. 


\section{Atención profesional en atención domiciliaria para niños y adolescentes con necesidades especiales de salud: una revisión integradora}

\section{Resumen}

Objetivo: Analizar los resultados de publicaciones científicas acerca de la atención domiciliar profesional a niños y adolescentes con necesidades especiales de salud. Materiales y método: Una revisión integradora con artículos publicados entre 2009 y 2020 realizada en las bases de datos BDEnf, Lilacs, Medline/PubMed y en la biblioteca electrónica SciELO. Se analizaron los datos en cuatro etapas: reducción de los datos; presentación de los datos; comparación de los datos; diseño y verificación de la conclusión. Resultados: Se identificaron 5641 artículos; luego de la aplicación de los criterios de inclusión y exclusión y descarte de los duplicados, se seleccionaron 637 artículos para la lectura de títulos y resúmenes, de los que 61 se seleccionaron para la lectura integral y de estos 28 compusieron la muestra final. Se identificaron la oferta de acciones de soporte remoto y la preocupación en capacitar los cuidadores en cuanto a los aspectos técnico-científicos del cuidado en el domicilio, además de la promoción de la mejoría de la calidad de vida de niños/ adolescentes y sus familiares. Se evidenció la laguna en relación con la identificación y el manejo del dolor por los profesionales de los servicios domiciliares. Conclusiones: La actuación de los servicios domiciliares a esta población específica enfoca en las demandas de cuidados con las tecnologías en salud y promoción de alivio de los síntomas, disminuyendo la carga de trabajo de los cuidadores y auxiliando en la deshospitalización.

\section{Palabras clave (Fuente: DeCS)}

Personas imposibilitadas; atención domiciliaria de salud; cuidador; niño; adolescente. 


\section{Assistência profissional no cuidado domiciliar de crianças e adolescentes com necessidades especiais de saúde: revisão integrativa}

\section{Resumo}

Objetivo: analisar os resultados de publicações científicas acerca da assistência domiciliar profissional às crianças e adolescentes com necessidades especiais de saúde. Materiais e método: revisão integrativa, com artigos publicados entre 2009 e 2020, realizada nas bases de dados BDEnf, Lilacs, Medline/PubMed e na biblioteca eletrônica SciELO. Os dados foram analisados em quatro etapas: redução dos dados; exibição dos dados; comparação dos dados; desenho e verificação da conclusão. Resultados: foram identificados 5641 artigos; após a aplicação dos critérios de inclusão e exclusão e descarte das duplicatas, foram eleitos 637 artigos para a leitura de títulos e resumos, dos quais 61 foram selecionados para a leitura na íntegra e destes, 28 compuseram a amostra final. Identificaram-se oferta de ações de suporte remoto e preocupação em capacitar os cuidadores quanto aos aspectos técnico-científicos do cuidado no domicílio, além da promoção da melhora da qualidade de vida das crianças/adolescentes e seus familiares. Evidenciou-se lacuna com relação à identificação e ao manejo da dor pelos profissionais dos serviços domiciliares. Conclusões: a atuação dos serviços domiciliares a essa população específica tem foco nas demandas de cuidados com as tecnologias em saúde e na promoção de alívio dos sintomas, diminuindo a carga de trabalho dos cuidadores e auxiliando na desospitalização.

\section{Palavras-chave (Fonte DeCS)}

Pacientes domiciliares; assistência domiciliar; cuidador; criança; adolescente. 
Child health care in Brazil has undergone advances evidenced by the reduction in infant mortality, increased access to health services, high vaccination coverage and decreased malnutrition. This resulted in the stagnation of neonatal mortality rates and an increase in the survival of premature children with chronic diseases (1).

In view of this change in the context of children's and youth health, there was the emergence of a group internationally entitled as "Children with Special Health Care Needs". These are children who present changes in their health status related to chronic conditions, functional limitations, need for recurrent use of complex health services or considerable risk of developing physical, developmental, behavior and emotional alterations. In general, they present demands for comprehensive and sometimes continuous and intense care (2). In Brazil, this group was named as "Child with special health needs" (Crianes) (3).

Because they also present specific care demands such as medication use, technological and development support, and habit modification, some Cubs can be clinically fragile. Thus, many families of these children and teenagers are socially vulnerable because they have low per capita income, aggravated by the restriction of the number of people who contribute financially to income due to the need for time of some of the family members to dedicate themselves to their care (4).

Depending on the special need for health, hospital admissions are recurrent and prolonged in this population group, resulting in an increase in the demand for care that, in the hospital, is performed by the members of the multidisciplinary team, but which, after clinical stability and hospital discharge, can be performed at home by the family (5). Therefore, the family is fundamental for the continuity of care because it is directly involved in the actions of meeting the basic needs of life up to the handling of complex health devices (6).

For home care, guidance on the management of devices and how to deal with their specificities is necessary. This training of the caregiver should be conducted from the moment of hospital admission. However, a study pointed out that these guidelines are provided in a segmented and sectorized way, in which professionals work with minimal integration, resulting in a multiprofessional gap and divergent information to families (7).

In Brazil, to meet the health demands of the Crianes and guide their families, it is necessary professional follow-up, either through punctual care, or continuous, according to each case, by multidisciplinary teams. In the public health system, these teams are linked to home care $(\mathrm{HC})$, defined as a modality of health care "characterized by a set of actions to prevent and treat diseases, rehabilitation, palliation and health promotion, provided at home, ensuring continuity of care" (8:1). 
The AD, in the country, is effected by Primary Care and/or the Home Care Service and proposes the provision of multiprofessional support and technical-scientific knowledge for family caregivers to continue comprehensive and humanized care, which allows the keep of a stable health condition for people who have some disease or chronic disease (9).

Therefore, the AD is configured as an ideal strategy to ensure the integrality of health care and meet the needs of families and continuous and complex care of the Crianes, because they go to the home equipped with technological devices such as: gastrostomy, tracheostomy, mechanical ventilation, oxygen therapy, nasoenteral tube, fully implanted catheter (10).

Therefore, to integrate the knowledge about this modality of health care promoted to the Crianes as a subsidy to professionals working in The A, the aim of this study is to analyze the results of scientific publications on professional home care for children and teenagers with special health needs.

\section{Materials and methods}

This is an integrative review of the literature, which was conducted in six phases: 1) identification of the problem, elaboration of the theme and the guiding question; 2) search of literature in electronic databases and libraries and selection of articles according to inclusion and exclusion criteria; 3 ) data collection and categorization of articles; 4) critical analysis of the included studies; 5) interpretation of the results; 6) presentation of the review (11).

The preparation of the guiding question was based on the PICO strategy, acronym for Participants, Interest and Context (12), in which: P - children and teenagers with special health needs; I home care; Co - performance of professionals of home care services to the Crianes.

Thus, the theme of this review is based on the following question: how has the performance of health professionals who compose home care services for children and teenagers with special health needs been? For classification purposes, the concept of home care services, present in the Virtual Health Library, was considered as: "community health services and nursing services that provide multiple and coordinated services to patients in their homes" (13). These home care services provide the visit of nurses, health units, hospitals or organized community groups that use specialized professional staff in the health area.

The literature search was conducted between December 2019 and February 2020, updated in March 2021, in the following databases: Nursing Database (BDEnf/VHL), Latin American and Caribbean Literature on Health Sciences (Lilacs/VHL), Medical Literature Analysis and Retrieval System online (Medline/PubMed) and electronic 
library Scientific Electronic Library Online (SciELO). We chose to select these bases because they are the most used in nursing research.

The Descriptors in Health Sciences (DeCS), in Portuguese and Spanish: Paciente domiciliares (Personas Imposibilitadas), Assistência Domiciliar (Atención Domiciliaria de Salud), Visita Domiciliar (Visita Domiciliaria), Criança (Niño), Adolescente (Adolescente). In English, the DeCS/ Medical Subject Headings (MeSH): child, adolescent, homebound persons, home care services, house calls.

The search strategy for obtaining the primary studies was performed through arrangements between descriptors and Boolean operators (AND and OR) with parentheses and quotation marks. In SciELO, Lilacs and BDEnf, the following search strategy was used: (teenager OR child) AND "home patients" OR "home care" OR "home visit" and its correspondents in Spanish and English; at Medline, Mesh: (child OR teenager) AND "homebound persons"; (child OR teenager) AND "home care services"; (child OR teenager) AND "home care services" AND "house calls".

The inclusion criteria of the studies were publications between 2009 and 2020, available in full, in Portuguese, English or Spanish, which presented individuals aged between $\mathrm{O}$ and 18, and that portrayed the proposed theme. Exclusion criteria were theses, dissertations and monographs, reviews, editorials, papers presented at scientific events, book chapters, obituary and letters to the editor.

The titles and abstracts were read independently to ensure that the elected articles met the question and inclusion criteria established. In cases of divergences, there was discussion among the researchers to reach consensus.

The process of selection and organization of articles occurred manually, based on the full reading and the use of a validated data extraction instrument for integrative review (14). This stage was performed independently by the two researchers, and the following steps were followed: data reduction, with the removal of the main results of the articles and coding for their better management; display of the data with the creation of a thematic framework, in which all articles and their respective codes are gathered; comparison of the data, in which patterns were identified in the codes, organizing them into groups with similar results, to which different colors were assigned for better definition of categories; and, in the final phase of drawing and verification of the conclusion, the synthesis of the resulting groups and their appointment into categories were carried out to enable the discussion (11).

\section{Results}

A total of 5,641 articles were identified, which, after applying the filters according to the inclusion criteria, resulted in 828. After the disposal of the manuscripts in duplicate, 637 (11/SciELO, 177/Lilacs, 26/ 
BDEnf and 423/Medline) had their titles and abstracts read exhaustively, to verify whether they answered the study question. A good of 576 articles were excluded because they were not in Portuguese, English or Spanish (1 article); do not present individuals aged between $o$ and 18 years ( 39 articles); not to be articles ( 9 works); not to respond to the research objective (527 articles).

After this stage, 61 articles were selected for full reading and, of these, 28 composed the final sample (Figure 1). Of the 61 studies, 32 were excluded for not answering the research question (2/SciELO; 3/Lilacs; 27/Medline) and one for not corresponding to the established age group (Lilacs).

Figure 1. Flowchart of the process of selecting articles in databases.
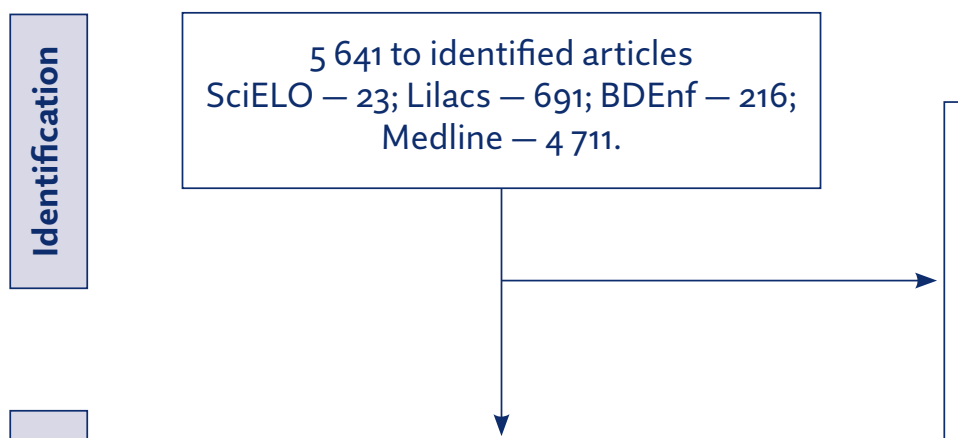

3706 were not published between 2009 and 2020.

1027 were not available in full. 46 were not articles.

34 did not present individuals aged between 0 and 18 .
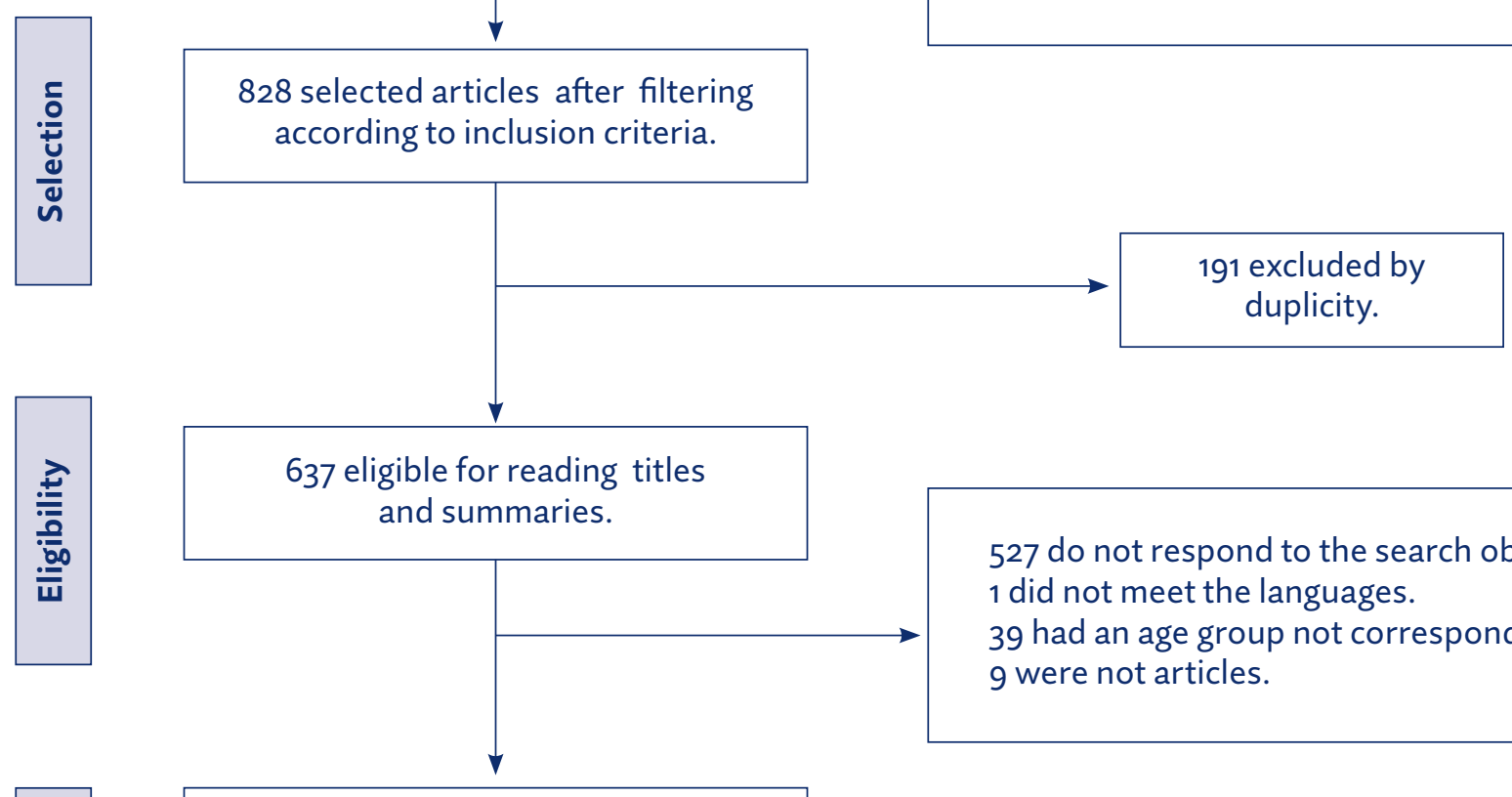

527 do not respond to the search object. 1 did not meet the languages.

39 had an age group not corresponding. 9 were not articles.
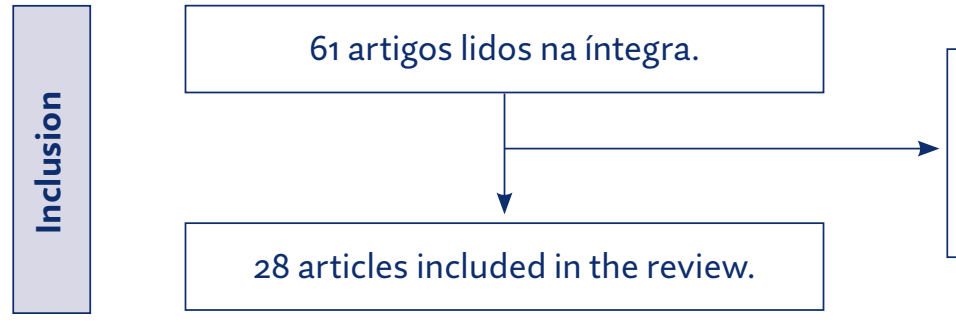

32 did not answer the question of the survey. 1 did not correspond to the age group required. 
Of the articles, eight (28.5\%) were published in 2016; four (14.2 \%) in 2019; (10.7 \%) in 2015 and 2014; (7.1\%) in each of the following years 2013, 2017 and 2018; (3.5 \%) in each of the years 2010, 2011, 2012 and 2020. In 2009, no studies addressing the theme were found. Regarding the research design, $24(85.7 \%)$ were quantitative studies, one $(3.5 \%)$ qualitative and three $(10.7 \%)$ addressed qualitative and quantitative methods (Chart 1).

The special health needs identified were related to diseases of respiratory (15), renal (16), neurological, cardiovascular, genetic, congenital, neoplastic and metabolic (17), infectious etiology (18). The professionals who performed home care were nurses, doctors, physiotherapists and occupational therapists (10).

After in-depth reading of the articles, the results were organized into three categories: Assistance to children and teenagers with evident symptoms and/or using health technologies; Factors that interfere with or promote health-related quality of life; Professional performance in home care with the family caregiver.

In addition to the categories listed, it was evidenced that AD brings benefits to the health system, because it optimizes the occupation of hospital beds by reducing the frequency of hospitalization. This can lead to the minimization of trauma to the Crianes by the lower exposure to stressors and the reduction of costs with hospital health expenses.

Table 1. Characterization of articles and categories listed on professional care in home care to children and teenagers with special health needs.

\begin{tabular}{|c|c|c|c|c|}
\hline $\begin{array}{c}\text { Author/year of } \\
\text { publication, database and } \\
\text { country }\end{array}$ & Title and method & $\begin{array}{l}\text { Category 1. Child and } \\
\text { teenager assistance with } \\
\text { obvious symptoms and/or in } \\
\text { use of health technologies }\end{array}$ & $\begin{array}{l}\text { Category 2. Factors that } \\
\text { interfere with or promote } \\
\text { health-related quality of life }\end{array}$ & $\begin{array}{l}\text { Category 3. Professional } \\
\text { performance in home care } \\
\text { with the family caregiver }\end{array}$ \\
\hline $\begin{array}{l}\text { Rossetto V, Toso BRGO, } \\
\text { Rodrigues RM, Viera CS, } \\
\text { Neves ET, 2019 (10) } \\
\text { SciELO } \\
\text { Brazil }\end{array}$ & $\begin{array}{l}\text { Development care for children } \\
\text { with special health needs in } \\
\text { home care at Paraná, Brazil } \\
\text { Quantitative }\end{array}$ & $\begin{array}{l}\text { Care with health devices } \\
\text { related to oxygenation, } \\
\text { urinary elimination and } \\
\text { feeding; rehabilitation; drug } \\
\text { dependence; use of diapers; } \\
\text { fully implanted catheter; and } \\
\text { other particular care. }\end{array}$ & ---- & ---- \\
\hline $\begin{array}{c}\text { Prado AF, Salinas FP, } \\
2013(15) \\
\text { Lilacs } \\
\text { Chile }\end{array}$ & $\begin{array}{c}\text { Home non-invasive ventilatory } \\
\text { care in children: initial impact of } \\
\text { a national program in Chile } \\
\text { Quantitative }\end{array}$ & $\begin{array}{l}\text { Noninvasive mechanical } \\
\text { ventilation assistance. }\end{array}$ & $\begin{array}{l}\text { Reduction of hospitalization; } \\
\text { quality of life; decreased of } \\
\text { anxiety. }\end{array}$ & $\begin{array}{l}\text { Provision of continuing } \\
\text { education to parents regarding } \\
\text { the management of the disease } \\
\text { and equipment. }\end{array}$ \\
\hline $\begin{array}{c}\text { Ellis EN, Blaszak C, Wright } \\
\text { S, Lierop AV, } 2012(16) \\
\text { Medline } \\
\text { United States of America }\end{array}$ & $\begin{array}{c}\text { Effectiveness of home visits } \\
\text { to pediatric peritoneal dialysis } \\
\text { patients } \\
\text { Quantitative }\end{array}$ & $\begin{array}{c}\text { Decrease in peritonitis, related } \\
\text { to care at the time peritoneal } \\
\text { dialysis. }\end{array}$ & ---------------- & $\begin{array}{l}\text { Family guidance on the use, } \\
\text { storage and administration } \\
\text { of medicinal products and } \\
\text { peritoneal dialysis and on care } \\
\text { for the environment/machine. }\end{array}$ \\
\hline $\begin{array}{l}\text { Groh G, Feddersen B, } \\
\text { Führer M, Borasio GD, } \\
2014(17) \\
\text { Medline } \\
\text { Germany }\end{array}$ & $\begin{array}{c}\text { Specialized home palliative } \\
\text { care for adults and children: } \\
\text { Differences and similarities } \\
\text { Quantitative }\end{array}$ & $\begin{array}{l}\text { Care for children with } \\
\text { neoplasia, metabolic } \\
\text { diseases, nervous system, } \\
\text { circulatory and congenital } \\
\text { with improvement of the } \\
\text { symptoms presented (pain, } \\
\text { fatigue, cognitive impairment, } \\
\text { dyspnea). }\end{array}$ & $\begin{array}{c}\text { Increased probability of } \\
\text { survival. }\end{array}$ & $\begin{array}{c}\text { Improves caregiver quality } \\
\text { of life by decreasing care } \\
\text { overload, anxiety and } \\
\text { depression. }\end{array}$ \\
\hline $\begin{array}{l}\text { Cantero MJP, Rodríguez } \\
\text { AM, Cardona ALU, Ortiz } \\
\text { AJ, } 2014 \text { (18) } \\
\text { Medline } \\
\text { Spain }\end{array}$ & $\begin{array}{c}\text { Domiciliary parenteral } \\
\text { antibiotic therapy: } \mathrm{A} \\
\text { prospective analysis of the last } \\
12 \text { years } \\
\text { Quantitative }\end{array}$ & $\begin{array}{l}\text { Administration of antibiotic } \\
\text { therapy. }\end{array}$ & $\begin{array}{l}\text { Reduction of hospitalization } \\
\text { and complication rates. }\end{array}$ & $\begin{array}{l}\text { Guidance to family caregivers } \\
\text { regarding the administration of } \\
\text { medications. }\end{array}$ \\
\hline
\end{tabular}




\begin{tabular}{|c|c|c|c|c|}
\hline $\begin{array}{c}\text { Author/year of } \\
\text { publication, database and } \\
\text { country }\end{array}$ & Title and method & $\begin{array}{l}\text { Category 1. Child and } \\
\text { teenager assistance with } \\
\text { obvious symptoms and/or in } \\
\text { use of health technologies }\end{array}$ & $\begin{array}{l}\text { Category 2. Factors that } \\
\text { interfere with or promote } \\
\text { health-related quality of life }\end{array}$ & $\begin{array}{l}\text { Category 3. Professional } \\
\text { performance in home care } \\
\text { with the family caregiver }\end{array}$ \\
\hline $\begin{array}{c}\text { Mariani FEP, Duarte ED, } \\
\text { Manzo BF, } 2016(19) \\
\text { Lilacs } \\
\text { Brazil }\end{array}$ & $\begin{array}{c}\text { Profile of children, adolescents } \\
\text { and their caregivers assisted by } \\
\text { a home care program } \\
\text { Quantitative }\end{array}$ & $\begin{array}{l}\text { Care with health devices } \\
\text { related to oxygenation, } \\
\text { feeding, neurological disorders } \\
\text { and drug administration. }\end{array}$ & & \\
\hline $\begin{array}{c}\text { Groh G, Borasio GD, } \\
\text { Nickolay C, Bender HU, } \\
\text { Von Lüttichau I, Führer M, } \\
2013(20) \\
\text { Medline } \\
\text { Germany }\end{array}$ & $\begin{array}{c}\text { Specialized pediatric palliative } \\
\text { home care: A prospective } \\
\text { evaluation } \\
\text { Qualitative and quantitative }\end{array}$ & $\begin{array}{l}\text { General care for children with } \\
\text { subsequent symptom control. }\end{array}$ & $\begin{array}{l}\text { Improves the quality of life of } \\
\text { caregivers/children. }\end{array}$ & $\begin{array}{l}\text { Relief of the burden of care } \\
\text { for caregivers, support for } \\
\text { their activities of daily living, } \\
\text { as well as psychological and } \\
\text { psychosocial support. }\end{array}$ \\
\hline $\begin{array}{l}\text { Han YJ, Park JD, Lee B, } \\
\text { Choi YH, Suh DI, Lim BC, } \\
\text { et al, } 2015(21) \\
\text { Medline } \\
\text { Korea }\end{array}$ & $\begin{array}{c}\text { Home mechanical ventilation } \\
\text { in childhood-onset hereditary } \\
\text { neuromuscular diseases: } 13 \\
\text { years' experience at a single } \\
\text { center in Korea } \\
\text { Quantitative }\end{array}$ & $\begin{array}{c}\text { Care with invasive and } \\
\text { noninvasive mechanical } \\
\text { ventilation, tracheostomy, } \\
\text { nasogastric tube and } \\
\text { gastrostomy. Decrease in } \\
\text { hypoxia episodes. }\end{array}$ & $\begin{array}{l}\text { Reduction of hospitalization; } \\
\text { the survival rate. }\end{array}$ & ---------------- \\
\hline $\begin{array}{c}\text { Yeager A, LaVigne AW, } \\
\text { Rajvanshi A, Mahato B, } \\
\text { Mohan R, Sharma R et al., } \\
2016(22) \\
\text { Medline } \\
\text { India }\end{array}$ & $\begin{array}{c}\text { Can Support: A model for } \\
\text { home-based palliative care } \\
\text { delivery in India } \\
\text { Qualitative and quantitative }\end{array}$ & $\begin{array}{l}\text { Administration of medications, } \\
\text { insertion of bladder and gastric } \\
\text { catheters; pain relief and } \\
\text { palliation. }\end{array}$ & --------------- & $\begin{array}{l}\text { Guidance to family members } \\
\text { regarding simple nursing tasks, } \\
\text { such as wound treatment. }\end{array}$ \\
\hline $\begin{array}{c}\text { Lindley LC, Mixer SJ, Mack } \\
\text { JW, } 2016 \text { (23) } \\
\text { Medline } \\
\text { United States of America }\end{array}$ & $\begin{array}{l}\text { Home care for children with } \\
\text { multiple complex chronic } \\
\text { conditions at the end of life: } \\
\text { The choice of hospice versus } \\
\text { home health } \\
\text { Quantitative }\end{array}$ & $\begin{array}{l}\text { Care for children with } \\
\text { cardiovascular conditions, } \\
\text { anomalies and decreased } \\
\text { functional status. }\end{array}$ & ------- & $\begin{array}{l}\text { Training of family caregivers; } \\
\text { ease of access to pediatric } \\
\text { reference hospitals. }\end{array}$ \\
\hline $\begin{array}{c}\text { Chong LA, Khalid F, } 2016 \\
(24) \\
\text { Medline } \\
\text { Malaysia }\end{array}$ & $\begin{array}{c}\text { Pediatric palliative care } \\
\text { at home: A single center's } \\
\text { experience } \\
\text { Quantitative }\end{array}$ & $\begin{array}{c}\text { Palliation and care with health } \\
\text { devices related to oxygenation, } \\
\text { urinary elimination and } \\
\text { feeding. Difficulty in pain } \\
\text { management. }\end{array}$ & ---- & --------------- \\
\hline $\begin{array}{c}\text { Tiberg I, Lindgren B, } \\
\text { Carlsson A, Hallström I, } \\
2016 \text { (25) } \\
\text { Medline } \\
\text { Sweden }\end{array}$ & $\begin{array}{l}\text { Cost-effectiveness and cost- } \\
\text { utility analyses of hospital- } \\
\text { based home care compared } \\
\text { to hospital-based care for } \\
\text { children diagnosed with type } \\
1 \text { diabetes; a randomized } \\
\text { controlled trial; results after } \\
\text { two years' follow-up } \\
\text { Quantitative }\end{array}$ & -------_------- & -------- & $\begin{array}{l}\text { Promoting parents' satisfaction } \\
\text { with home care. From the } \\
\text { presentation to the family of } \\
\text { strategies for the management } \\
\text { of diabetes that have an impact } \\
\text { on daily life for a longer period. }\end{array}$ \\
\hline $\begin{array}{l}\text { Lindley LC, Nageswaran S, } \\
2017(26) \\
\text { Medline } \\
\text { United States of America }\end{array}$ & $\begin{array}{c}\text { Pediatric primary care } \\
\text { involvement in end-of-life care } \\
\text { for children } \\
\text { Quantitative }\end{array}$ & --_-_-_-_------- & $\begin{array}{l}\text { Relationship between home } \\
\text { care and approximation } \\
\text { with primary care; beyond } \\
\text { decreased predisposition to } \\
\text { cardiovascular, psychological } \\
\text { and functional problems. }\end{array}$ & ----------------- \\
\hline $\begin{array}{c}\text { Chong PH, De Castro } \\
\text { Molina JA, Teo K, Tan WS, } \\
2018(27) \\
\text { Medline Singapore }\end{array}$ & $\begin{array}{c}\text { Pediatric palliative care } \\
\text { improves patient outcomes } \\
\text { and reduces health care costs: } \\
\text { Evaluation of a home-based } \\
\text { program } \\
\text { Quantitative }\end{array}$ & $\begin{array}{l}\text { Decreased pain } \\
\text { during follow-up. }\end{array}$ & $\begin{array}{l}\text { Reduction of hospital } \\
\text { admissions; improve of } \\
\text { emotions; quality of life } \\
\text { related to health. }\end{array}$ & $\begin{array}{c}\text { Reduction of caregiver care } \\
\text { burden. }\end{array}$ \\
\hline $\begin{array}{l}\text { Carvalho AJL, Ferreira HM, } \\
\text { Borges EF, Borges Junior } \\
\text { LH, de Paula ALT, Hattori } \\
\text { WT et al., 2019 (28) } \\
\text { Medline } \\
\text { Brazil }\end{array}$ & $\begin{array}{c}\text { Analyses of the effectiveness of } \\
\text { a Brazilian pediatric home care } \\
\text { services: A preliminary study } \\
\text { Quantitative }\end{array}$ & ---------------- & $\begin{array}{l}\text { Decreased infection rates, } \\
\text { procedures (laboratory and } \\
\text { imaging tests) and readmission. }\end{array}$ & \\
\hline $\begin{array}{c}\text { Lee YH, Lu CW, Huang CT, } \\
\text { Chang HH, Yang KC, Kuo } \\
\text { CS et al., 2019 (29) } \\
\text { Medline } \\
\text { China }\end{array}$ & $\begin{array}{l}\text { Impact of a home health care } \\
\text { program for disabled patients } \\
\text { in Taiwan: A nationwide } \\
\text { population-based cohort study } \\
\text { Quantitative }\end{array}$ & $\begin{array}{l}\text { Care of tubes or catheters and } \\
\text { treatment of wounds. }\end{array}$ & $\begin{array}{l}\text { Reduction of the risks of } \\
\text { hospitalization and the use of } \\
\text { emergency services. }\end{array}$ & \\
\hline
\end{tabular}




\begin{tabular}{|c|c|c|c|c|}
\hline $\begin{array}{l}\text { Author/year of } \\
\text { publication, database and } \\
\text { country }\end{array}$ & Title and method & $\begin{array}{l}\text { Category 1. Child and } \\
\text { teenager assistance with } \\
\text { obvious symptoms and/or in } \\
\text { use of health technologies }\end{array}$ & $\begin{array}{l}\text { Category 2. Factors that } \\
\text { interfere with or promote } \\
\text { health-related quality of life }\end{array}$ & $\begin{array}{l}\text { Category 3. Professional } \\
\text { performance in home care } \\
\text { with the family caregiver }\end{array}$ \\
\hline $\begin{array}{l}\text { Naicker SN, Richter L, } \\
\text { Stein A, Campbell L, } \\
\text { Marston J, } 2016 \text { (30) } \\
\text { Medline } \\
\text { South Africa }\end{array}$ & $\begin{array}{l}\text { Development and pilot } \\
\text { evaluation of a home-based } \\
\text { palliative care training and } \\
\text { support package for young } \\
\text { children in Southern Africa } \\
\text { Qualitative }\end{array}$ & $\begin{array}{l}\text { Adequate pain management } \\
\text { during home follow-up. }\end{array}$ & $\begin{array}{l}\text { Greater permanence of the } \\
\text { child in the home; favoring the } \\
\text { approach of the child with the } \\
\text { family members. }\end{array}$ & $\begin{array}{l}\text { Promotion of support and } \\
\text { preparation of the family for } \\
\text { the experience of death, in } \\
\text { addition to the mediation of } \\
\text { learning for the performance } \\
\text { of home care. }\end{array}$ \\
\hline $\begin{array}{l}\text { Tang MH, Lin CK, Lin WH, } \\
\text { Chen CH, Tsai SW, Chang } \\
\text { YY, 2011 (31) } \\
\text { Medline } \\
\text { China }\end{array}$ & $\begin{array}{l}\text { The effect of adding a } \\
\text { home program to weekly } \\
\text { institutional-based therapy } \\
\text { for children with undefined } \\
\text { developmental delay: A pilot } \\
\text { randomized clinical trial } \\
\text { Quantitative }\end{array}$ & ---------------- & $\begin{array}{l}\text { The home activity program } \\
\text { resulted in average functional } \\
\text { progress when compared to } \\
\text { institutional therapy in terms } \\
\text { of cognitive, language, motor } \\
\text { activities and social domains. }\end{array}$ & $\begin{array}{l}\text { Guidance and training on home } \\
\text { management of children with } \\
\text { developmental delay through } \\
\text { rehabilitation activities. }\end{array}$ \\
\hline $\begin{array}{c}\text { Maynard R, Christensen E, } \\
\text { Cady R, Jacob A, Ouellette } \\
\text { Y, Podgorski H et al., } 2019 \\
\text { (32) } \\
\text { Medline } \\
\text { United States of América }\end{array}$ & $\begin{array}{l}\text { Home health care availability } \\
\text { and discharge delays in children } \\
\text { with medical complexity } \\
\text { Quantitative }\end{array}$ & $\begin{array}{l}\text { Tracheostomy, gastrostomy, } \\
\text { nasogastric tube, jejunostomy, } \\
\text { nasal cannula, mechanical } \\
\text { ventilation, among others. }\end{array}$ & $\begin{array}{l}\text { Delayed initiation of home care } \\
\text { reduces the quality of life of } \\
\text { children and increases the risk } \\
\text { of infection. }\end{array}$ & ------ \\
\hline $\begin{array}{c}\text { Zuurmond M, O'Banion D, } \\
\text { Gladstone M, Carsamar S, } \\
\text { Kerac M, Baltussen M, et } \\
\text { al., 2018 (33) } \\
\text { Medline } \\
\text { Ghana }\end{array}$ & $\begin{array}{c}\text { Evaluating the impact of a } \\
\text { community-based parent } \\
\text { training program for children } \\
\text { with cerebral palsy in Ghana } \\
\text { Quantitative }\end{array}$ & --------------- & $\begin{array}{l}\text { Significant improvement in the } \\
\text { physical and emotional health } \\
\text { of the child and improvement } \\
\text { in some aspects in infant } \\
\text { feeding (some children were } \\
\text { malnourished). }\end{array}$ & $\begin{array}{l}\text { The home support to the } \\
\text { parents provided an increase } \\
\text { in the number of patients and } \\
\text { significant improvement in the } \\
\text { knowledge and confidence of } \\
\text { the family caregivers. }\end{array}$ \\
\hline $\begin{array}{c}\text { Ferre CL, Brandão M, } \\
\text { Surana B, Dew AP, Moreau } \\
\text { NG, Gordon AM, 2017 (34) } \\
\text { Medline } \\
\text { United States of America }\end{array}$ & $\begin{array}{l}\text { Caregiver-directed home- } \\
\text { based intensive bimanual } \\
\text { training in young children with } \\
\text { unilateral spastic cerebral } \\
\text { palsy: A randomized trial } \\
\text { Quantitative }\end{array}$ & $\begin{array}{l}\text { Improved bimanual dexterity } \\
\text { and occupational performance. }\end{array}$ & ------------------ & $\begin{array}{l}\text { Training for performing } \\
\text { exercises at home to } \\
\text { improve bimanual hand } \\
\text { control, increasing parent- } \\
\text { child interaction; remote } \\
\text { professional follow-up (online). }\end{array}$ \\
\hline $\begin{array}{c}\text { Mankikar D, Campbell C, } \\
\text { Greenberg R, } 2016 \text { (35) } \\
\text { Medline } \\
\text { United States of America }\end{array}$ & $\begin{array}{l}\text { Evaluation of a home-based } \\
\text { environmental and educational } \\
\text { intervention to improve health } \\
\text { in vulnerable households: } \\
\text { Southeastern Pennsylvania } \\
\text { Lead and Healthy Homes } \\
\text { Program } \\
\text { Quantitative }\end{array}$ & & $\begin{array}{l}\text { Reduction of hospital } \\
\text { admissions and medical } \\
\text { consultations. }\end{array}$ & $\begin{array}{l}\text { Health education for the } \\
\text { adaptation of the environment } \\
\text { and asthma control. }\end{array}$ \\
\hline $\begin{array}{c}\text { Perera H, Jeewandara KC, } \\
\text { Seneviratne S, Guruge C, } \\
2016(36) \\
\text { Medline } \\
\text { Sri Lanka }\end{array}$ & $\begin{array}{l}\text { Outcome of home-based } \\
\text { early intervention for autism } \\
\text { in Sri Lanka: Follow-up of a } \\
\text { cohort and comparison with a } \\
\text { nonintervention group } \\
\text { Quantitative }\end{array}$ & & $\begin{array}{l}\text { Improvement of eye contact, } \\
\text { response to name, social } \\
\text { reciprocity, imitative } \\
\text { behavior and pointing. }\end{array}$ & $\begin{array}{l}\text { Guidance and training to } \\
\text { stimulate, in a playful way, at } \\
\text { home, the social interaction } \\
\text { and communication of children. }\end{array}$ \\
\hline $\begin{array}{l}\text { Lorentzen J, Greve LZ, } \\
\text { Kliim-Due M, Rasmussen } \\
\text { B, Bilde PE, Nielsen JB, } \\
2015(37) \\
\text { Medline Denmark }\end{array}$ & $\begin{array}{l}\text { Twenty weeks of home-based } \\
\text { interactive training of children } \\
\text { with cerebral palsy improves } \\
\text { functional abilities } \\
\text { Quantitative }\end{array}$ & ---- & $\begin{array}{l}\text { Improvement of activities of } \\
\text { daily living resulting in greater } \\
\text { school participation and } \\
\text { leisure. }\end{array}$ & \\
\hline $\begin{array}{c}\text { Eskow KG, Chasson GS, } \\
\text { Summers JA, } 2015(38) \\
\text { Medline } \\
\text { United States of America }\end{array}$ & $\begin{array}{c}\text { A cross-sectional cohort study } \\
\text { of a large, statewide Medicaid } \\
\text { home and community-based } \\
\text { services autism waiver program } \\
\text { Quantitative }\end{array}$ & 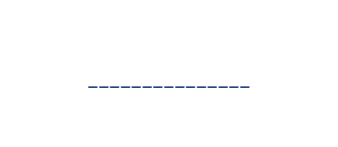 & $\begin{array}{l}\text { Improved skills in activities } \\
\text { that could be performed } \\
\text { independently. }\end{array}$ & $\begin{array}{l}\text { Support for family members } \\
\text { provided an improvement in } \\
\text { the quality of life of the family. }\end{array}$ \\
\hline $\begin{array}{c}\text { Hoyt Drazen C, Abel R, } \\
\text { Lindsey T, King AA, } 2014 \\
\text { (39) } \\
\text { Medline } \\
\text { United States of America }\end{array}$ & $\begin{array}{l}\text { Development and feasibility of } \\
\text { a home-based education model } \\
\text { for families of children with } \\
\text { sickle cell disease } \\
\text { Qualitative and quantitative }\end{array}$ & & 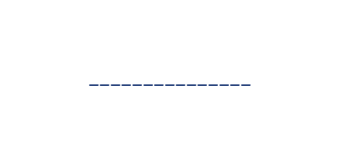 & $\begin{array}{l}\text { Conducting educational } \\
\text { actions on the milestones of } \\
\text { development, learning and } \\
\text { skills appropriate for early } \\
\text { childhood. }\end{array}$ \\
\hline $\begin{array}{c}\text { Potterton J, Stewart A, } \\
\text { Cooper P, Becker P, } 2010 \\
(40) \\
\text { Medline } \\
\text { South Africa }\end{array}$ & $\begin{array}{l}\text { The effect of a basic home } \\
\text { stimulation program on the } \\
\text { development of young children } \\
\text { infected with HIV } \\
\text { Quantitative }\end{array}$ & & $\begin{array}{l}\text { Positive effect on the } \\
\text { neurodevelopmental status of } \\
\text { children with HIV. }\end{array}$ & $\begin{array}{l}\text { Guidelines for performing } \\
\text { activities that stimulate } \\
\text { neurodevelopment. }\end{array}$ \\
\hline $\begin{array}{c}\text { Dangel T, Kmieć } \\
\text { T, Januszaniec A, Ważny B, } \\
2020(41) \\
\text { Medline } \\
\text { Poland }\end{array}$ & $\begin{array}{l}\text { Palliative care in } 9 \text { children with } \\
\text { neurodegeneration with brain } \\
\text { iron accumulation } \\
\text { Quantitative }\end{array}$ & $\begin{array}{l}\text { Aid in the control of pain } \\
\text { and other symptoms; brain } \\
\text { stimulation; administration of } \\
\text { medicines; oxygen-therapy. }\end{array}$ & & $\begin{array}{l}\text { Family support for home care } \\
\text { addressing emotional and } \\
\text { spiritual aspects. }\end{array}$ \\
\hline
\end{tabular}

Source: Own elaboration. 


\section{Discussion}

$\mathrm{HC}$ is recognized for effective actions of rehabilitation, palliation, health promotion, prevention and treatment of diseases. It aims to increase the autonomy of the user, family and caregiver, taking responsibility for the management and operationalization of care or home hospitalization. It requires qualified health professionals who offer home support to the user and their caregiver (8), according to the discussion of the following categories.

\section{Child and teenager assistance with obvious symptoms and/or in use of health technologies}

The performance of health professionals in home services is focused on technological health support, especially the care of invasive and noninvasive mechanical ventilation, tracheostomy, gastrostomy, oxygen therapy, peritoneal ventricle bypass, nasoenteral/nasogastric tube, fully implanted catheter, urinary catheters, as well as assistance to symptoms presented by the child and teenager such as pain, fatigue, cognitive impairment, and dyspnea (10, 15-24, 27, 29, 30, 32, 34).

The conduction of these care stems from the fact that the Crianes present a prominent subgroup: children and teenagers with complex chronic conditions (CCC). These are characterized as multisystemic diseases that permeate their birth, growth and development, often leading to technological dependence and prolonged stay in hospitals (41).

The CCC was responsible for the prevalence of $84.2 \%$ of pediatric hospitalizations, especially genetic and congenital anomalies ( 80.8 $\%)$, respiratory diseases (68\%), neuromuscular diseases (47.3\%) and gastrointestinal diseases (42.4\%). After hospital discharge, many required home health technologies, such as gastrostomy (29.6\%), oxygen therapy (7.4\%), special milk formulas ( $4.4 \%)$ and noninvasive mechanical ventilation (2\%) (9\%).

It is evident that children with CCC have multidimensional needs, depending on professional care plus family care (42). Thus, referral to $\mathrm{HC}$ can be effected and bring benefits, such as the reduction of suffering caused by hospitalization and increased availability of beds for acute conditions (9).

Another potential of $\mathrm{HC}$ is related to the increase in the quality of care for health technologies, evidenced in research conducted with children on home peritoneal dialysis and their families (16). In this study, there was a decrease in the rates of peritonitis in children after professional interventions at home when compared with the incidence of this complication only with family care.

Another group of Crianes that stood out was that of children and teenagers in palliative care in receiving home care, because, in ad- 
dition to support with health technologies, they needed special attention to symptoms arising from their health conditions (17, 2224). A study in Germany pointed out that, after the involvement of the pediatric palliative home care team, the companions perceived a significant improvement in the symptoms presented by children and teenagers (17).

This was possible because, when they received treatment in the comfort of the household, they did not awaken a feeling of sadness as occurred in the hospital and needed less constant and difficult visits to the health service (43). On the other hand, a study states that there is difficulty in recognizing and managing pain, a symptom prevalent in patients receiving palliative care, and it is necessary to advance in the conduction of care plans, such as through scales or protocols that enable the measurement of this vital signal (24).

The construction of the care plan conducted by the home service team should cover the needs of patients, starting from the evaluation of physical, psychological, emotional, basic diagnosis and understanding of the social relationships in which they are involved. Thus, each professional will perform actions that fall into his or her category.

The services that provide home care excel in the quality of care, using health technologies required by each child, who experiences home care. Thus, they provide compliance with the demands arising from the condition of the Crianes, maintaining the possible stability, which results in a better quality of life for the child and his/her family.

\section{Factors that promote or interfere with health- related quality of life}

It is evident the increase in the quality of life related to the health of the Crianes after the interventions of the professionals who provide home care, in the following aspects: reduction of hospital rehospitalizations and rates of complications such as infections; reduction in the constant performance of procedures such as laboratory tests and search for emergency services; improvement of emotions, anxiety, cognition, language and activities of daily living; survival rates $(15,17,18,20,21,26-29,31,37)$.

The increase in hospital stay, triggered by the delay in the beginning of home care, results in a decrease in the quality of life of the Children and an increased risk of infections. A study points out that this delay is due to the lack of professionals with good financial incentive, adequate workload and migration in search of good working conditions (32).

Moreover, the multiple hospitalizations decrease their survival, further aggravated when CCC is present (45). These adversities are little present in timely home hospitalizations, as pointed out in a stud, in which the number of hospitalizations, procedures and number of 
infections decrease significantly in home services when compared to hospital services (28).

Therefore, the HC has the potential to reduce the hospital demand and the permanence of users in prolonged hospitalizations, complementing the care provided by primary care services. In this perspective, there is a reduction in the use of emergency services, sometimes required by the Crianes after hospital discharge (29).

Consequently, the increase in home stay and the performance of these services in an environment in which the Crianes feel safe, results in the improvement of the quality of life related to health. Studies that evaluated home palliative services to children showed that, in the opinion of parents or caregivers, the quality of life of their children improved significantly after the involvement of these services $(17,20)$.

In addition, the involvement of professionals in home care results in an improvement in emotional state, anxiety and levels of depression of both the child and the caregiver after home interventions $(15,17)$. These benefits are justified by actions such as that of a Malaysian service, which provides 24-hour telephone access, providing physical and emotional support to its patients and caregivers (27).

Children with neurodevelopmental delay need special attention from home professionals. Therefore, in the impossibility of an integral professional, the orientations and training of parents to perform home activities bring positive responses to the quality of life of these children (31). However, for family involvement to become effective, in ensuring adequate child neurodevelopment, a strategy used is to fit the routine activities of the family and child and teenager from stimulating activities, as pointed out research conducted with family members of children with HIV (40).

Another strategy in improving daily activities, which guarantee an excellent quality of life, such as leisure, school participation, attention of children with cognitive impairment, is the application of computer interventions in the online modality by parents, prescribed by professionals and with sporadic follow-up. In this modality, because it is possible to perform constant and intense interventions, without the limitations of weekly care only with the professional, the development of The Crianes occurs considerably (37).

But the continuous availability of support is still an essential component for the home caregiver, because, in addition to providing safety and help, it prepares them for the adversities that may arise at any stage of the disease, either in times of urgency or in the resolution of the doubts of the caregivers themselves. Therefore, it favors continuous and comprehensive health care (27).

In view of the above, the professionals of home care services, performing frequent care to the Crianes, guarantee them a longer sur- 
vival, if they have adequate working conditions $(18,20)$. The constant monitoring, in the physical, emotional and cognitive scope, using strategies beyond the presence of professionals such as the use of computers, internet and telephone, makes the improvement of the quality of life of this public be achieved, which brings benefits that radiate to family members, parents, caregivers who take care of these children daily.

\section{Performance of health professionals in the home service with the family caregiver}

In families conformed by Crianes, it is common to observe emotional stress, frustration and disappointment of mothers caused by the lack of knowledge of their pathology and resources that are necessary for care $(46,47)$. In addition, the exclusive dedication of mothers in the care of The Crianes, due to the lack of support network that assists them, causes the abandonment of their jobs, a financial deficit and lack of self-care, affecting family well-being $(48,49)$.

Studies indicate that family members also be afraid in the handling of technological devices, such as tracheostomy (50) and gastrostomy (51), in the usual care such as bathing and feeding, in the administration of medication and its long-term effects, being evidenced by unpreparedness in situations of complication and infection (52).

It is note that the importance that family members must acquire technical-scientific knowledge to promote adequate care to the Crianes, being necessary notions of mathematics, disinfection, drug interaction, handling of health technologies, among others (5).

The performance of home service professionals, portrayed in the literature investigated in this study, strongly highlights the offer of technical and scientific knowledge to family members. These actions are focused on guidance and training on the correct management of invasive devices, the use, storage and correct administration of medications and the daily care to Crianes $(15,16,20,22,23,25)$.

The recognition of families by health professionals enables their active participation in the care process, performing activities safely (6). This is highlighted in a home care unit in Spain, where professionals train parents or caregivers to administer antimicrobial therapy intravenously long enough for them to feel safe to continue at home, in the absence of professionals (20).

Moreover, family involvement is more effective when therapeutic actions are also delegated to parents and inserted in the daily life of the family and in the playful activities performed with the Crianes. This occurred in a home intervention program for autistic children, resulting in an improvement in social interaction, language and communication (36); in a home exercise program for bimanual hand control for children with cerebral palsy, resulting in greater father-child interaction (34). 
Although this family involvement is advantageous, caution is necessary in conducting therapeutic activities at home, considering that these interventions tend to change the family routine and require the caregiver to have a psychosocial well-being to implement them. Therefore, it is up to the professionals to outline with the caregiver the best time and daily time necessary for the activities to be performed with the children and teenagers so as not to overload them (34).

Preventive education is also part of the work of health professionals of The $\mathrm{HC}$ with family members, referring to the monitoring of child development and the reduction of environmental factors that interfere in the health status of the Crianes. This was evidenced in studies in which preventive education modifies parental behavior for the adaptation of the home environment, making it safer and with the possibility of conducting activities appropriate to children and teenagers (39).

These actions of prevention, guidance and training, and the involvement of home services professionals in the care of the Crianes contributed significantly to the reduction of the work overload of the caregivers. In addition, there was a reduction in their psychological distress evidenced in the minimum prevalence of diseases such as anxiety and depression, implying an increase in the quality of life of family members $(17,20,27)$.

The receipt of home care provides families with more time for everyday life, not turning exclusively to the care of the Crianes, partially returning to the common activities existing before the presence of this condition. Moreover, it is emphasized the strengthening of relationships with relatives and friends, and the decrease in constant family displacement to the hospital, resulting in an increase in the physical and mental disposition for home care (43).

The family members/caregivers of Crianes are in the act of performing previously unusual activities. Thus, the services that provide home care seek to meet the needs of technical and scientific knowledge of family members through prevention actions, guidance and training, both for care and in actions that improve the mental health and quality of life of the Children and their families.

\section{Conclusion}

The present study allowed the analysis of the performance of health professionals in home care services to The Created at national and international level. However, in a continental country like Brazil, not all municipalities have these services in place. As in other countries, although with different denominations for AD in Brazil, it can be observed that these services act in the demands of care with health technologies, promote relief of the symptoms presented and reduce the workload of caregivers and family members. Moreover, it was possible to identify the offer of remote support actions and concern to train caregivers regarding the technical-scientific aspects of the care of the Crianes and the management of their health conditions. 
The provision of these services is not only limited to the presence of professionals at home but can also be performed using technologies such as internet, computers and telephone. This expands and strengthens the parent-professional relationship, resulting in feelings of safety and improvement of the quality of life related to the health of parents and Crianes.

Professionals working in the home care service present difficulties in identifying and managing pain. This is a gap that could be minimized by the implementation of scales and protocols to measure this signal, generating greater comfort to the child and tranquility to the family. Another gap in care was the delay in the beginning of home care, with a subsequent increase in the stay of Crianes in the hospital.

It should be noted that there was a limitation of the search in the databases due to the lack of a specific descriptor for Crianes, since this term encompasses a diversity of groups of children and teenagers with special health needs. In addition, the present study was based on the Brazilian model of home care, so that, as observed in the reading of the articles, there is a variety of organizations in this modality of care; thus, it cannot be generalized to all the realities of the world. Therefore, it is suggested the development of research with the objective of longitudinally monitoring the performance of health professionals of home care in other countries of the world, according to their specificities, focusing on pain management and the time necessary for the organization of the team and the dehospitalization of Crianes.

This review brings as a benefit the unification of information on The Services of $\mathrm{HC}$ for the Crianes, enabling those interested in the area to understand them as an aid to dehospitalization. It also subsidizes professionals in the care of children at home, since it summarizes the main evidence of the methods used by health professionals in $\mathrm{HC}$ to this public.

Bringing to the fore how professional care has been taking place in the home care of Crianes can give visibility to this population that, in fact, requires continuous and comprehensive care, and deserves to live with dignity. To this end, awareness and changes in the work process of those who care for them are necessary.

Conflict of interest: None declared. 
1. Branquinho ID, Lanza FM. Child health in primary care: Evolution of Brazilian policies and nurses' performance. RECOM. 2018;8:e2753. DOI: https://doi.org/10.19175/recom.v8io.2753

2. McPherson M, Arango P, Fox H, Lauver C, McManus M, Newacheck PW et al. A new definition of children with special health care needs. Pediatrics. 1998;102(1):137-9. DOI: https://doi. org/10.1542/peds.102.1.137

3. Arrué AM, Neves ET, Magnago TSBS, Cabral IE, Gama SGN, Hökerberg YHM. Translation and adaptation of children with special health care needs screener into Brazilian Portuguese. Cad. Saúde Pública. 2016;32(6):eo0130215. DOI: https://doi. org/10.1590/0102-311X00130215

4. Dias BC, Arruda GO, Marcon SS. Family vulnerability of children with special needs of multiple, complex and continuous care. Rev Min Enferm. 2017;21:e1027. DOI: https://doi.org/10.5935/14152762.20170037

5. Simonasse MF, Moraes JRMM. Children with special health needs: Impact on family life. R. pesq. cuid. fundam. online. 2015;7(3):2902-9. DOI: https://doi.org/10.9789/2175-5361.2015. v7i3.2902-2909

6. Inácio ALR, Peixoto APGL. Nursing care and family care for children with special health needs: Integrative literature review. Rev. Aten. Saúde. 2017;15(53):87-94. DOI: https://doi.org/10.13037/ras. vol15n53.4593

7. Góes FGB, Cabral IE. Hospital discharge in children with special health care needs and its different dimensions. Rev. Enferm. UERJ. 2017;25:e18684. DOI: https://doi.org/10.12957/reuerj.2017.18684

8. Ministério da Saúde do Brasil. Portaria n. ${ }^{\circ} 825$ de 25 de abril de 2016. Redefine a Atenção Domiciliar no âmbito do Sistema Único de Saúde (SUS) e atualiza as equipes habilitadas. Diário oficial da União 26 de abril de 2016; seção 1.

9. Ministério da Saúde do Brasil; Secretaria de Atenção à Saúde; Departamento de Ações Programáticas Estratégicas; Coordenação Geral de Saúde da Criança e Aleitamento Materno; Departamento de Atenção Hospitalar e Urgências; Coordenação Geral de Atenção Domiciliar. Nota informativa: Atenção Domiciliar Neonatal e Pediátrica no Brasil. Brasília: Ministério da Saúde; 2016.

10. Rossetto V, Toso BRGO, Rodrigues RM, Viera CS, Neves ET. Development care for children with special health needs in home care at Paraná-Brazil. Esc. Anna Nery. 2019;23(1):1-10. DOI: https://doi. org/10.159o/2177-9465-ean-2018-0067

11. Whittemore R, Knafl K. The integrative review: Updated methodology. JAN. 2005;52(5):546-53. DOI: https://doi.org/10.1111/j.13652648.2005.03621.X

12. Karino ME, Felli VEA. Enfermagem baseada em evidências: avanços e inovações em revisões sistemáticas. Cienc Cuid. Saúde. 2012;11(5):011-5. DOI: https://doi.org/10.4025/cienccuidsaude. v11i5.17048

13. Biblioteca Virtual em Saúde [internet]. Descritores em Ciências da Saúde: Serviço de Assistência Domiciliar. São Paulo (SP): Bireme/ OPAS/OMS; 2017 [citado em 8 de novembro de 2021]. Disponível em: https://decs.bvsalud.org/ths/resource/?id=6856\&filter=ths_ termall\&q=assist $\% C_{3} \%$ AAncia\%2odomiciliar

14. Ursi ES. Prevenção de lesões de pele no perioperatório: revisão integrativa da literatura [Dissertação]. Ribeirão Preto (SP): Universidade de São Paulo; 2005.

15. Prado AF, Salinas FP. At-home non-invasive ventilatory assistance for children: Initial impact of a national program in Chile. Rev. Chil. Pediatr. 2011;82(4):289-99. Disponível em: https://dx.doi. org/10.4067/s0370-41062011000400003
16. Ellis EN, Blaszak C, Wright S, Lierop AV. Effectiveness of home visits to pediatric peritoneal dialysis patients. PDI. 2012;32(4):41923. DOI: https://doi.org/10.3747/pdi.2010.00145

17. Groh G, Feddersen B, Führer M, Borasio GD. Specialized home palliative care for adults and children: differences and similarities. J Palliat Med. 2014;17(7):803-10. DOI: https://doi.org/10.1089/ jpm.2013.0581

18. Cantero MJP, Rodríguez AM, Cardona ALU, Ortiz AJ. Domiciliary parenteral antibiotic therapy: A prospective analysis of the last 12 years. An Pediatr (Barc). 2014;81(2):86-91. DOI: https://doi. org/10.1016/j.anpedi.2013.05.009

19. Mariani FEP, Duarte ED, Manzo BF. Profile of children, teenagers and their caregivers assisted by a home care program. Rev Rene. 2016;17(1):137-43. DOI: https://doi.org/10.15253/21756783.2016000100018

20. Groh G, Borasio GD, Nickolay C, Bender HU, Von Lüttichau I, Führer M. Specialized pediatric palliative home care: A prospective evaluation. J Palliat Med. 2013;16(12):1588-94. DOI: https://doi. org/10.1089/jpm.2013.0129

21. Han YJ, Park JD, Lee B, Choi YH, Suh DI, Lim BC et al. Home mechanical ventilation in childhood-onset hereditary neuromuscular diseases: 13 years' experience at a single center in Korea. PLoS One. 2015;10(3):e0122346. DOI: https://doi.org/10.1371/journal. pone. 0122346

22. Yeager A, LaVigne AW, Rajvanshi A, Mahato B, Mohan R, Sharma R, Grover S. CanSupport: A model for home-based palliative care delivery in India. Ann Palliat Med. 2016;5(3):166-71. DOI: https:// doi.org/10.21037/apm.2016.05.04

23. Lindley LC, Mixer SJ, Mack JW. Home care children with multiple complex chronic conditions ate the end of life: The choice of hospice versus home health. Home Health Care Serv. Q. 2016;35(34):101-11. DOI: https://doi.org/10.108o/01621424.2016.1208133

24. Chong LA, Khalid F. Paediatric palliative care at home: A single center's experience. Singapore Med J. 2016;57(2):77-80. DOI: https://doi.org/10.11622/smedj.2016032

25. Tiberg I, Lindgren B, Carlsson A, Hallström I. Cost-effectiveness and cost-utility analyses of hospital-based home care compared to hospital-based care for children diagnosed with type 1 diabetes; a randomized controlled trial; results after two years' follow-up. BMC Pediatr. 2016;16(94):1-12. DOI: https://doi. org/10.1186/s12887-016-0632-8

26. Lindley LC, Nageswaran S. Pediatric primary care involvement in end-of-life care for children. Am. J. Hosp. Palliat. Care. 2017;34(2):135-41. DOI: https://doi.org/10.1177/1049909115609589

27. Chong PH, De Castro Molina JA, Teo K, Tan WS. Paediatric palliative care improves patient outcomes and reduces healthcare costs: Evaluation of a home-based program. BMC Palliat. Care. 2018;17(11):1-8. DOI: https://doi.org/10.1186/s12904-017-0267-z

28. Carvalho AJL, Ferreira HM, Borges EF, Borges Junior LH, de Paula ALT, Hattori WT et al. Analyses of the effectiveness of a Brazilian pediatric home care service: A preliminary study. BMC Health Serv. Res. 2019;19:324. DOI: https://doi.org/10.1186/s12913-0194148-4

29. Lee YH, Lu CW, Huang CT, Chang HH, Yang KC, Kuo CS, Chang YK, Hsu CC, Huang KC. Impact of a home health care program for disabled patients in Taiwan: A nationwide population-based cohort study. Medicine. 2019;98(7):e14502. DOI: https://doi.org/10.1097/ MD.0000000000014502

30. Naicker SN, Richter L, Stein A, Campbell L, Marston J. Development and pilot evaluation of a home-based palliative care training 
and support package for young children in southern Africa. BMC Palliat Care. 2016;9:15-41. DOI: https://doi.org/10.1186/s12904016-0114-7

31. Tang MH, Lin CK, Lin WH, Chen CH, Tsai SW, Chang YY. The effect of adding a home program to weekly institutional-based therapy for children with undefined developmental delay: A pilot randomized clinical trial. J. Chin. Med. Assoc. 2011;74(6):25966. DOI: https://doi.org/10.1016/j.jcma.2011.04.005

32. Maynard R, Christensen E, Cady R, Jacob A, Ouellette Y, Podgorski H, Schiltz B, Schwantes S, Wheeler W. Home Health care availability and discharge delays in children with medical complexity. Pediatrics. 2019;143(1):e20181951. DOI: https://doi. org/10.1542/peds.2018-1951

33. Zuurmond M, O'Banion D, Gladstone M, Carsamar S, Kerac M, Baltussen M, Tann CJ, Gyamah Nyante G, Polack S. Evaluating the impact of a community-based parent training program for children with cerebral palsy in Ghana. PLoS One. 2018;13(9):e0202096. DOI: https://doi.org/10.1371/journal. pone.0202096

34. Ferre CL, Brandão M, Surana B, Dew AP, Moreau NG, Gordon AM. Caregiver-directed home-based intensive bimanual training in young children with unilateral spastic cerebral palsy: A randomized trial. Dev. Med. Child. Neurol. 2017;59(5):497-504. DOI: https://doi.org/10.1111/dmcn.13330

35. Mankikar D, Campbell C, Greenberg R. Evaluation of a homebased environmental and educational intervention to improve health in vulnerable households: Southeastern Pennsylvania lead and healthy homes program. Int. J. Environ. Res. Public. Health. 2016;13(9):900. DOI: https://doi.org/10.339o/ ijerph13090900

36. Perera H, Jeewandara KC, Seneviratne S, Guruge C. Outcome of home-based early intervention for autism in Sri Lanka: Follow-Up of a cohort and comparison with a nonintervention group. Biomed Res. Int. 2016;2016:1-6. DOI: https://doi. org/10.1155/2016/3284087

37. Lorentzen J, Greve LZ, Kliim-Due M, Rasmussen B, Bilde PE, Nielsen JB. Twenty weeks of home-based interactive training of children with cerebral palsy improves functional abilities. BMC Neurol. 2015;15:75. DOI: https://doi.org/10.1186/s12883-0150334-०

38. Eskow KG, Chasson GS, Summers JA. A cross-sectional cohort study of a large, statewide Medicaid home and community-based services autism waiver program. J. Autism. Dev. Disord. 2015;45(3):626-35. DOI: https://doi.org/10.1007/s10803014-2217-4

39. Hoyt Drazen C, Abel R, Lindsey T, King AA. Development and feasibility of a home-based education model for families of children with sickle cell disease. BMC Public. Health. 2014;14:116. DOI: https://doi.org/10.1186/1471-2458-14-116

40. Potterton J, Stewart A, Cooper P, Becker P. The effect of a basic home stimulation program on the development of young children infected with HIV. Dev. Med. Child. Neurol. 2010;52(6):54751. DOI: https://doi.org/10.1111/j.1469-8749.2009.03534.x
41. Dangel $T$, Kmieć $T$, Januszaniec $A$, Ważny B. Palliative care in 9 children with neurodegeneration with brain iron accumulation. Neurol. Sci 2020;41(3):653-60. DOI: https://doi.org/10.1007/ s10072-019-04099-5

42. Moreira MCN, Albernaz LV, Sá MRCD, Correia RF, Tanabe RF. Recommendations for a line of care for children and teenagers with complex chronic health conditions. Cad. Saúde Pública. 2017;33(11):eo0189516. DOI: https://doi.org/10.1590/0102$311 \times 00189516$

43. Martins PL, Azevedo CS, Afonso SBC. The role of family in treatment plans and pediatric inpatient care in complex chronic health conditions. Saude soc. 2018; 27(4):1218-29. DOI: https:// doi.org/10.159o/s0104-12902018170402

44. Castor C, Landgren K, Hallstrom IK. A possibility for strengthening family life and health: Family members' lived experience when a sick child receives home care in Sweden. Health Soc. Care Community. 2018;26:224-31. DOI: https://doi.org/10.1111/ hsc.12512

45. Oliveira AJ, Ribeiro AL, Lima JSD, Horta NC. Performance of home care teams in palliative care. Percurso Acadêmico. 2019;9(18):39-58. DOI: https://doi.org/10.5752/P.2236o6o3.2019vgn18p71-9o

46. Kalzén H, Larsson B, Eksborg S, Lindberg L, Edberg KE, Frostell C. Survival after PICU admission: The impact of multiple admissions and complex chronic conditions. PLoS One. 2018;13(4);114. DOI: https://doi.org/10.1371/journal.pone.0193294

47. Santos CCT, Miranda CSSP, Silva KDJM, Pinto MFP, Costa AS, Moraes-Filho IM. Emotional stress in families of children with special needs-literature review. REICEN. 2018;1(2):247-9. Disponível em: https://revistasfacesa.senaaires.com.br/index.php/ iniciacao-cientifica/article/view/89

48. Reis KMN, Alves GV, Barbosa TA, Lomba GO, Braga PP. A vivência da família no cuidado domiciliar à criança com necessidades especiais de saúde. Cienc. Enferm. 2017;23(1):45-55. DOI: https:// doi.org/10.4067/S0717-95532017000100045

49. Leite FLLM, Gomes GC, Minasi ASA, Nobre CMG, Mota MS. Facilidades e dificuldades vivenciadas pela família no cuidado à criança com necessidades especiais de saúde. Res., Soc. Dev. 2020; 9(10):e5619108761. DOI: https://doi.org/10.33448/rsdvgi10.8761

50. Bossa PMA, Pacheco STA, Araújo BBM, Nunes MDR, Silva LF, Cardoso JMRM. Desafios de familiares no cuidado domiciliar da criança em uso de cânula de traqueostomia. Rev. Enferm. UERJ. 2019;27:e43335. DOI: https://doi.org/10.12957/reuerj.2019.43335

51. Nóbrega VM, Araújo MGF, Coutinho LRPC, Oliveira CKN, Dantas JC, Collet N. Vivências maternas no cuidado à criança gastrostomizada: subsídios para atuação da equipe de saúde. Rev Min Enferm. 2019;23:e-1250. DOI: https://doi.org/10.5935/14152762.20190098

52. Barros ABS. Dúvidas dos familiares de crianças com necessidades especiais de saúde quanto aos cuidados domiciliares [Trabalho de conclusão de curso]. Niterói (RJ): Universidade Federal Fluminense; 2016. 